\title{
Gambaran celebrity worship pada penggemar K-Pop usia dewasa awal di Bali
}

\author{
Dyana Putri Kristina Sintya Dewi dan Komang Rahayu Indrawati \\ Program Studi Sarjana Psikologi Fakultas Kedokteran Universitas Udayana \\ komangrahayu.indraw@gmail.com
}

\begin{abstract}
Abstrak
Celebrity worship merupakan suatu kecenderungan untuk memformulasikan kedekatan dengan seorang idola, yang mengarah kepada perilaku disfungsional (Rojek, 2012). Berdasarkan fakta di lapangan, diketahui bahwa pada penggemar K-Pop usia dewasa awal masih terlibat dalam celebrity worship. Hal tersebut terlihat dari berbagai aktivitas yang dilakukan penggemar K-Pop usia dewasa awal untuk menunjukkan ekspresi cinta kepada idola K-Pop yang terkadang dianggap terlalu berlebihan, obsesif, delusif, dan posesif. Celebrity worship berpotensi menghambat perkembangan usia dewasa awal untuk membangun hubungan intim dengan orang lain. Penelitian ini bertujuan untuk mengetahui gambaran celebrity worship pada penggemar K-Pop Bali. Metode penelitian yang digunakan adalah penelitian kualitatif dengan pendektan fenomenologi. Pengumpulan data dilakukan dengan teknik wawancara mendalam, observasi, dan pengumpulan bahan visual pada empat penggemar K-Pop Bali. Seluruh responden berjenis kelamin perempuan dan berusia antara 21-22 tahun yang dipilih dengan teknik purposive sampling. Hasil penelitian menunjukkan bahwa celebrity worship mencakup alasan menyukai idola, motivasi pengidolaan, dan aktivitas pengidolaan. Hasil penelitian juga menemukan bentuk baru dari celebrity worship, yaitu supportive idolization pada penggemar K-Pop usia dewasa awal di Bali.
\end{abstract}

Kata kunci: Celebrity worship, dewasa awal, K-Pop

\begin{abstract}
Celebrity worship is a tendency to formulate an over-close identiffication with a celebrity, leading to dysfunctional behaviour (Rojek, 2012). Based on the fact in the field, shows that celebrity worship still appears in early adult K-Pop fans. It can be see through the K-Pop fan activities that sometimes deemed to be over, obsessive, possessive, and delusive while expressing their love toward K-Pop idol. Celebrity worship has the potential to hamper the early adulthood developmental tasks to build intimate relationships with others. This study aims to find out the description of celebrity worship on Balinese K-Pop fans. The method of this research was qualitative with phenomenological approach. The data were collected from in-depth interview, observation, and visual material collection on four Balinese K-Pop fans. All of them are females and age between 21-22 years who were selected by purposive sampling technique. The results showed that celebrity worship in early adult K-Pop fans contain the reason for liking K-Pop, idolization motivation, and idolization activity. The results also found a supportive idolization as a new stage of celebrity worship on early adult K-Pop Fans in Bali.
\end{abstract}

Keywords: Celebrity worship, early adulthood, K-Pop 


\section{LATAR BELAKANG}

Globalisasi menyebabkan semakin mudah masuknya nilainilai serta budaya dari suatu negara ke negara lain, salah satu contoh budaya yang berkembang di berbagai belahan dunia adalah musik Korean Pop atau lebih dikenal dengan K-Pop. K-Pop atau Korean Pop didefinisikan sebagai suatu bentuk spesifik dari musik dengan term yang tidak merujuk pada keseluruhan musik populer asli Korea, melainkan dihubungkan dengan gagasan "idol music" - sebuah sub-genre yang mewakili orientasi bintang industri hiburan kaum muda yang berkaitan erat dengan industri televisi (Ubonrat \& Shin, 2007). Gaya musik yang enerjik dan semangat membuat KPop terdengar unik sehingga disukai banyak kalangan (KOCIS, 2011).

Berdasarkan hasil studi pendahuluan berupa survei secara online yang dilakukan pada 70 orang Bali penggemar K-Pop yang berasal dari Kota Denpasar, Kabupaten Badung, Kabupaten Bangli, Kabupaten Klungkung, Kabupaten Gianyar, dan Kabupaten Tabanan, diketahui bahwa $66 \%$ penggemar K-Pop berada pada rentang usia 19 - 21 tahun, $26 \%$ berada pada rentang usia 15 - 18 tahun, dan $8 \%$ pada rentang usia di atas 21 tahun (Dewi, 2017). Hal tersebut menunjukkan bahwa di Bali, masih terdapat penggemar K-Pop yang berada pada rentang usia dewasa awal. Sejalan dengan hasil penelitian Boon dan Lomore (2001) yang menyatakan bahwa $75 \%$ individu pada usia dewasa awal memiliki ketertarikan yang kuat terhadap celebrity dalam kehidupan individu tersebut, dengan sebagian besar ketertarikan terhadap idola pop, bintang film, dan figur lainnya.

Perasaan nyaman yang didapatkan penggemar K-Pop dari idola menimbulkan suatu proses timbal balik bagi penggemar untuk menunjukkan rasa cinta kepada idola yang disukai. Berseberangan dengan persepsi yang berkembang di masyarakat, perilaku yang dilakukan penggemar K-Pop dalam mengekspresikan cinta untuk para idola kerap dianggap berlebihan dan dinilai terlalu esktrem, hingga penggemar KPop sering dianggap obsesif, posesif, dan bahkan delusif (Zahrotustianah \& Puspitasari, 2016). Ekspresi cinta yang ditunjukkan penggemar K-Pop merupakan suatu bentuk pemujaan terhadap idola. Semakin tinggi tingkat pemujaan seseorang, maka tingkat keterlibatan dengan idola juga semakin tinggi (Darfiyanti \& Putra, 2012).

Pemujaan kepada celebrity atau yang dikenal dengan istilah celebrity worship didefinisikan sebagai suatu kecenderungan untuk memformulasikan kedekatan dengan seorang idola yang mengarah kepada perilaku disfungsional (Rojek, 2012). Celebrity worship dibagi menjadi tiga tahapan, yaitu entertainment social, motivasi yang mendasari pencarian aktif penggemar terhadap celebrity atau idola yang disukai; intensepersonal feeling, refleksi perasaan intensif dan kompulsif terhadap celebrity atau idola; dan borderline-pathological, sikap seperti kesediaan melakukan apapun demi celebrity atau idola (Maltby, Giles, Barber, \& McCutcheon, 2005).

Individu begitu juga penggemar K-Pop usia dewasa awal yang terlibat dalam celebrity worship merupakan seseorang yang insecure dan putus asa terhadap kelekatan dan relatif tidak mampu secara layak menjaga batas antara dunia nyata dan maya (Meloy, Sheridan, \& Hoffman, 2008). Menurut Erikson (Feist \& Feist, 2014) perasaan tergila-gila akan seseorang yang biasa ditemui pada masa remaja bukanlah keintiman yang sebenarnya ketika individu memasuki usia dewasa awal sebab individu mulai mengalami suatu krisis psikososial, yaitu intimasi versus isolasi. Keintiman yang matang berarti kemampuan dan kemauan berbagi rasa percaya yang timbal balik serta melibatkan pengorbanan, kompromi, dan komitmen dalam hubungan dua orang yang setara (Feist \& Feist, 2014).

Hubungan intim dengan orang lain dapat dimulai dengan adanya interaksi. Pada masyarakat Hindu Bali, interaksi merupakan aktivitas ritualistik dan religius dengan dibatasi oleh dua afektif yang menonjol yaitu rasa malu dan kecenderungan mengabaikan masalah, sehingga secara kasat mata membuat hubungan interpersonal menjadi lebih terbatas serta tidak tercapainya keputusan untuk penyelesaian masalah (Geertz, 1973). Hal ini tanpa disadari dapat mengarahkan individu pada keterasingan.

Di sisi lain, kehidupan masyarakat Bali yang dilandasi oleh nilai-nilai budaya seperti sosial religius, kerja kolektif, tiru meniru, gotong-royong, serta sakral (Lodra, 2017) dapat mencegah penggemar K-Pop usia dewasa awal di Bali terhindar dari celebrity worship. Matlby, et al. (2002), menemukan bahwa salah satu cara meminimalisisr celebrity worship adalah ketika individu menjadi pribadi yang religius dan memiliki kepatuhan tinggi terhadap Tuhan, dengan demikian individu tersebut cenderung mengabaikan serta memiliki kemungkinan yang lebih kecil untuk terlibat dalam celebrity worship.

Berdasarkan paparan di atas diketahui bahwa K-Pop merupakan salah satu jenis musik yang tidak terlepas dari adanya idola K-Pop, dianggap dapat membantu mengatasi masalah emosional sekaligus berpotensi menimbulkan keterlibatan dalam celebrity worship pada penggemar usia dewasa awal. Penelitian ini bertujuan untuk mengetahui bagaimana gambaran celebrity worship pada penggemar KPop usia dewasa awal di Bali.

\section{METODE PENELITIAN}

\section{Tipe penelitian}

Penelitian ini menggunakan metode penelitian kualitatif dengan pendekatan fenomenologi. Fenomenologi sering digunakan sebagai pandangan umum untuk menunjukkan pengalaman subjektif dari berbagai jenis dan tipe subjek yang ditemui dan fokus pada pengalaman-pengalaman subjektif manusia (Moleong, 2014). Penelitian ini menggunakan satuan kajian pada level kelompok, yaitu kelompok penggemar KPop usia dewasa awal di Bali, untuk mendapatkan pemahaman serta informasi yang lebih mendalam mengenai gambaran celebrity worship pada penggemar K-Pop usia dewasa awal di Bali.

\section{Responden penelitian}

Pencarian responden ditentukan dengan teknik purposive sampling, yaitu teknik penentuan responden dengan pertimbangan kriteria-kriteria tertentu yang harus dimiliki oleh individu sebagai responden (Sugiyono, 2014). Kriteria responden dalam penelitian ini, yaitu: 1) individu usia dewasa 
awal, dengan rentang usia 18 hingga kira-kira 40 tahun; 2) individu usia dewasa awal penggemar K-Pop yang belum memiliki pasangan dan belum menikah; 3) beragama Hindu; dan 4) berasal dari Bali.

\section{Teknik penggalian data}

Teknik pengambilan data yang digunakan dalam penelitian ini adalah wawancara, observasi, dan bahan visual.

1. Wawancara

Menurut Esterberg (dalam Sugiyono, 2014), wawancara adalah pertemuan antara dua orang yang dilakukan untuk bertukar informasi dan ide melalui tanya jawab, sehingga dapat dikonstruksikan makna dalam suatu topik tertentu. Pada penelitian ini, teknik wawancara yang digunakan adalah wawancara semistruktur, wawancara yang termasuk dalam kategori in-depth interview, akan tetapi dalam pelaksanaannya lebih bebas dibandingkan dengan wawancara terstruktur (Esterberg dalam Sugiyono, 2014). Metode ini dipilih dengan tujuan untuk memperoleh data dan memungkinkan untuk menggali informasi yang menarik selama pelaksanaan penelitian.

2. Observasi

Cristensen (dalam Sugiyono, 2014) menjelaskan bahwa observasi dalam sebuah penelitian diartikan sebagai pengamatan terhadap pola perilaku manusia dalam situasi tertentu untuk mendapatkan informasi tentang fenomena yang diinginkan. Penelitian ini menggunakan jenis observasi partisipasi pasif agar peneliti dapat fokus mengamati situasi dan perilaku responden penelitian dengan objektif dan observasi terus terang karena peneliti harus menyampaikan prosedur penelitian kepada responden melalui informed consent sesuai dengan etika penelitian. Hal yang ingin diungkap dalam observasi dalam penelitian ini adalah reaksi, perilaku, dan ekspresi yang cenderung ditampilkan selama proses wawancara.

3. Bahan Visual

Bahan visual merupakan berbagai bentuk dari bahan fotografi. Roland Barthes (dalam Bungin, 2007) menyatakan bahwa fotografi sebagai pesan yang dapat diidentifikasi namun untuk dapat menginterpretasi haruslah memiliki pengetahuan yang cukup. Macammacam jenis bahan fotografi antara lain foto, grafis, film, video, kartun, mikrofilm, slide, dan sebagainya sehingga disebut bahan visual. Bahan visual merupakan bahan informasi sekunder (Bungin, 2007).

\section{Teknik analisis data}

Penelitian ini menggunakan teknik analisis data Miles dan Huberman (dalam Bungin, 2007), yang meliputi: (1) reduksi data; (2) penyajian data, dan (3) mengambil kesimpulan lalu diverifikasi. Reduksi data merupakan proses pemilihan, pemusatan perhatian pada penyederhanaan, pengabstrakan, dan transformasi data "kasar" yang muncul dari catatancatatan tertulis di lokasi penelitian (Bungin, 2007). Penyajian data merupakan sekumpulan informasi tersusun yang memberi kemungkinan adanya penarikan kesimpulan dan pengambilan tindakan, sehingga peneliti akan dapat memahami apa yang sedang terjadi dan apa yang harus dilakukan berdasarkan pemahaman yang didapat peneliti melalui penyajian tersebut (Bungin, 2007). Penarikan kesimpulan merupakan proses untuk mulai mencari benda-benda, mencatat keteraturan, polapola, penjelasan, konfigurasi-konfigurasi yang mungkin, alur sebab akibat, dan proposisi, sehingga dalam penelitian muncul temuan baru yang sebelumnya belum pernah ada (Bungin, 2007).

\section{HASIL PENELITIAN}

Berdasarkan kode-kode hasil pengambilan data yang diperoleh selama pelaksanaan sesi wawancara, observasi, pengumpulan bahan visual, serta telah melalui tahap analisis data dengan menggunakan pendekatan fenomenologi, hasil penelitian pada penggemar K-Pop usia dewasa awal di Bali meliputi alasan menyukai K-Pop, motivasi pengidolaan, aktivitas pengidolaan, dan tahapan celebrity worship yang ditemukan dari keempat responden penelitian, yaitu supportive idolization. Berikut karakteristik keempat responden penelitian: (Tabel terlampir)

\section{Alasan Menyukai K-Pop}

Keempat responden menyukai K-Pop sejak usia remaja. Keberadaan idola K-Pop dalam hidup responden hingga memasuki usia dewasa awal disebabkan oleh beberapa alasan, yaitu keempat responden menyukai K-Pop adalah idol visual, idol stage performance, idol music, dan idol attitude.

Idol visual merujuk pada wajah idola yang tampan, kulit putih, dan cara berpakaian yang kekinian menarik minat untuk menyukai idola K-Pop. Idol stage performance merupakan kemampuan menyanyi, menari secara kompak dengan sesama anggota grup dari idola K-Pop yang disukai, serta penataan panggung saat idola K-Pop tampil. Idol music merupakan alasan menyukai K-Pop karena musik yang dibawakan idola K-Pop mudah dan menyenangkan untuk didengar, genre musik yang ditampilkan beragam sehingga menambah pengetahuan bagi responden tentang musik, serta lagu yang dinyanyikan idola sesuai dengan emosi yang dirasakan penggemar. Idol attitude merupakan alasan menyukai K-Pop karena sikap yang ditampilkan idola K-Pop dianggap dapat memberikan contoh baik sehingga dapat memicu responden untuk menjadi seperti idola, antara lain: sikap profesional dengan tersenyum dalam setiap keadaan serta dapat membedakan masalah pribadi dan pekerjaan; kerja keras; dan tekun.

\section{Motivasi Pengidolaan}

Motivasi pengidolaan adalah segala hal yang mendorong responden untuk melakukan aktivitas sebagai penggemar KPop. Motivasi pengidolaan muncul setelah responden memiliki alasan untuk menyukai idola K-Pop. Motivasi pengidolaan dibagi menjadi dua bagian, yaitu motivasi jangka panjang dan motivasi jangka pendek.

Motivasi jangka panjang adalah motivasi pengidolaan yang berasal dari dalam diri keempat responden. Motivasi yang timbul merupakan hasil dari lamanya waktu yang dihabiskan untuk menyukai idola K-Pop dan tetap timbul dalam hidup keempat responden untuk jangka waktu yang panjang. 
Inspired to success merupakan motivasi yang didapat dari idola K-Pop berupa contoh agar keempat responden berusaha untuk berhasil dalam hidup, berusaha mencapai tujuan sendiri, yakin mampu menghadapi situasi yang serupa seperti idola $\mathrm{K}$ Pop, serta berusaha untuk meluapkan emosi yang dirasakan kemudian melanjutkan hidup. Avoid to stop adalah kehadiran idola K-Pop sejak usia remaja, menyebabkan berhenti menyukai idola K-Pop di usia dewasa awal terasa sulit, sebab idola K-Pop sudah menjadi bagian hidup responden serta merasa ada yang hilang jika idola K-Pop tidak ada dalam hidup responden. Culture interest adalah ketertarikan akan budaya Korea, seperti tertarik untuk belajar bahasa dan huruf Korea, serta anggapan bahwa budaya K-Pop sebagai budaya yang baru sehingga menarik dan menghibur.

Motivasi jangka pendek merupakan motivasi pengidolaan yang berasal dari luar diri keempat responden. Motivasi timbul selama proses mencapai tujuan yang diinginkan dari suatu aktivitas berlangsung dan berkurang secara perlahan ketika tujuan dari suatu aktivitas telah terpenuhi. Meet idol muncul sebab keempat responden terbiasa melihat idola K-Pop melalui video memiliki keinginan untuk pergi ke Korea dengan tujuan untuk bertemu secara langsung dengan idola serta melihat secara langsung lokasi-lokasi di Korea yang pernah ditunjukkan idola K-Pop kepada penggemar melalui video yang ditonton. Seeking for support system, yaitu responden tanpa disadari mulai bergantung dengan keberadaan idola K-Pop setelah menyukai idola K-Pop dalam jangka waktu yang lama, sehingga menyebabkan timbulnya perasaan idola K-Pop sebagai support system. Support atau dukungan dari idola K-Pop dirasakan ketika tidak ada yang mampu menemani setiap saat, ketika tidak ada yang dapat diandalkan, merasa sudah mengenal idola K-Pop yang disukai, dan merasa dukungan yang didapat dari keluarga belum cukup.

\section{Aktivitas Pengidolaan}

Idol support adalah upaya yang dilakukan responden untuk menyatakan dukungan kepada idola K-Pop yang disukai. Tujuan dari idol support adalah untuk membantu idola K-Pop yang disukai mendapat penghargaan. Pembelian merchandise merupakan aktivitas keempat responden untuk membeli benda-benda yang berkaitan dengan idola K-Pop termasuk album, setelah melakukan pertimbangan prioritas serta manfaat pembelian aksesoris K-Pop tersebut. Mendengarkan lagu secara perlahan membuat responden merasa bahwa lagu K-Pop dapat mengurangi beban pikiran dan memperbaiki suasana hati yang buruk. Menonton video klip karena perasaan suka menonton idola, untuk membantu idola masuk ke suatu penghargaan, serta merupakan totalitas sebagai penggemar. Menabung merupakan kegiatan menyisihkan uang yang dimiliki oleh keempat responden penelitian sebagai persiapan membeli album, aksesoris K-Pop, tiket konser, juga untuk rencana pergi ke Korea. Voting dilakukan untuk memberi dukungan kepada idola K-Pop yang disukai di suatu penghargaan melalui penggunaan akun media sosial.

Seeking information atau aktivitas pencarian informasi adalah aktivitas keempat responden mencari tahu informasi tentang idola K-Pop yang disukai melalui akun media sosial yang dimiliki dan browsing internet untuk mengetahui kebenaran dari sikap yang ditunjukkan oleh idola kepada penggemar juga untuk mengetahui aktivitas yang dilakukan idola K-Pop yang disukai. Fans interaction adalah interaksi dengan sesama penggemar K-Pop yang mencakup aktivitas kumpul bersama, sharing informasi mengenai idola K-Pop yang disukai, dan curhat. Interaksi dengan sesama penggemar K-Pop yang lain menyebabkan pertemanan yang berlangsung lama dan dekat, hingga mampu menceritakan curahan hati kepada teman sesama penggemar K-Pop tersebut.

\section{Celebrity Worship Tahapan Supportive Idolization}

Keempat responden berada pada suatu tahapan baru dari celebrity worship, yaitu tahapan supportive idolization. Supportive idolization merupakan tahapan celebrity worship yang berada di antara tahapan entertainment-social dan juga intense-personal. Supportive idolization adalah bentuk pemujaan kepada idola K-Pop dengan hanya menjadikan idola sebagai idola di atas panggung. Responden menyadari bahwa idola K-Pop memiliki kehidupan lain sebagai manusia dibalik kehidupan sebagai celebrity. Responden juga menyadari bahwa idola K-Pop bukan merupakan prioritas dalam hidup dan menyadari realita dalam hidup responden, yaitu tanggung jawab di usia dewasa awal seperti bekerja, melanjutkan pendidikan, dan mulai mencari pasangan. Pada bentuk ini, responden tetap menjukkan dukungan terhadap idola namun dengan intensitas yang lebih rendah dibanding saat remaja.

Responden pada supportive idolization mampu membatasi penggunaan akun media sosial untuk mencari informasi mengenai idola dengan memberikan batasan berapa lama waktu yang dapat digunakan setiap hari untuk mengakses informasi tentang idola K-Pop dan hanya fokus kepada informasi yang dianggap penting, contohnya berita idola menikah atau berpacaran dan mengabaikan informasi lainnya yang tidak dianggap penting mengenai idola K-Pop yang disukai. Penggemar pada bentuk supportive idolization mampu menunjukkan empati terhadap idola K-Pop yang disukai. Empati adalah perasaan yang dirasakan keempat responden selama menjadi penggemar K-Pop sesuai dengan apa yang dirasakan idola K-Pop yang disukai. Penggemar pada bentuk supportive idolization mampu merasakan empati namun belum mampu menunjukkan kepada banyak orang karena adanya kontrol terhadap perasaan atau control of feeling, yang dilakukan dengan menyembunyikan rasa kesal dan marah ketika idola yang disukai tidak dihargai dan diejek, sebab keempat responden merasa hal tersebut hanya hal sepele, membela diri menyebabkan responden semakin diserang oleh yang memberi ejekan, dan memilih untuk tidak terpancing secara emosi. Keempat responden juga menyatakan idola K-Pop hanya dianggap sebagai role model sedangkan arahan dan tujuan hidup responden berasal dari ajaran agama Hindu, sehingga pada tahapan supportive idolization juga dipengaruhi oleh religiusitas keempat responden penelitian.

\section{PEMBAHASAN DAN KESIMPULAN}


Celebrity worship merupakan suatu pengabdian seseorang kepada setidaknya satu tokoh dalam posisi terpapar media dan status publik (Houran dalam Meloy, Sheridan, \& Hoffman, 2008). Hasil penelitian McCutcheon, Lange, dan Houran (2002); Raviv, Bal-Tar, dan Ben-Horin (1996), menemukan bahwa celebrity worship mencapai puncaknya pada usia remaja pada usia 11-17 tahun, dan menurun perlahan pada usia dewasa. Pada penelitian ini diketahui bahwa celebrity worship masih terjadi pada keempat responden yang merupaka penggemar K-Pop berusia 21 dan 22 tahun di Bali. Keempat responden sudah memasuki usia dewasa awal menurut (Hurlock, 2015). Temuan ini sejalan dengan hasil penelitian penelitian Widjaja dan Ali (2015), yaitu dewasa awal masih melakukan pemujaan terhadap idola.

Pemujaan terhadap celebrity atau celebrity worship dapat dipengaruhi oleh berbagai hal. Pada penelitian ini ditemukan bahwa celebrity worship pada penggemar K-Pop diawali dengan adanya alasan untuk menyukai K-Pop. Alasan menyukai K-Pop meliputi idol visual, idol stage performance, idol music, serta idol attitude. Sejalan dengan hasil penelitian Dita Darfiyanti dan M.G. Bagus Ani Putra (2012) menunjukkan bahwa alasan awal partisipan menyukai idola pop adalah talenta dan atau fitur fisik idola yang disukai, ketika partisipan mulai mengenal idola pop yang disukai maka alasan menyukai idola pop semakin mengarah pada kualitas pribadi idola pop.

Alasan menyukai K-Pop menyebabkan munculnya motivasi pengidolaan pada keempat responden. Motivasi pengidolaan yang muncul pada keempat responden berupa motivasi jangka panjang yang meliputi inspired to success, avoid to stop, dan culture interest. Motivasi pengidolaan yang kedua adalah motivasi jangka pendek meliputi meet idol dan seeking for support system, dan sulit berhenti menyukai K-Pop. Responden menjadikan idola K-Pop sebagai sumber motivasi yang diperlukan untuk meningkatkan semangat dalam kehidupan sehari-hari responden. Hasil penelitian Sheridan (2017) yang menyatakan bahwa dampak posistif dari celebrity worship adalah membuat individu termotivasi untuk melakukan kegiatan tertentu. Individu yang menyukai celebrity hanya semata-mata karena hiburan dan alasan-alasan sosial akan menjadi pribadi yang lebih optimis, mudah bergaul, dan bahagia.

Responden yang sudah terbiasa dengan kehadiran K-Pop sejak usia remaja belum mampu untuk berhenti menyukai K-Pop, responden merasa ada yang hilang ketika idola K-Pop tidak ada lagi di dalam hidup responden, serta paparan media sosial yang menyajikan berita mengenai idola K-Pop menyebabkan timbulnya keingintahuan responden terhadap kabar idola KPop yang disukai. Pencarian informasi idola K-Pop dilakukan melalui aktivitas media sosial dan browsing internet. Hal tersebut dikarenakan responden menganggap informasi mengenai idola yang disukai lebih cepat dan mudah diakses melalui media sosial. Hal ini sesuai dengan definisi media sosial menurut Gunelius (2011), media sosial adalah penerbitan online, alat-alat komunikasi, situs, dan tujuan dari Web 2.0 yang berakar pada percakapan, keterlibatan, partisipasi yang kemudian dirancang untuk memudahkan interaksi sosial dua arah atau bersifat interaktif.

Responden yang terbiasa melihat idola K-Pop memiliki keinginan untuk pergi ke Korea dan tertarik budaya Korea. Idola K-Pop merupakan perantara untuk menyebarkan hasil produk budaya Korea Selatan yaitu musik K-Pop kepada masyarakat di seluruh dunia. Menurut Storey dan Laily (2006), penggemar merupakan konsumen ideal dikarenakan kebiasaan konsumsi mereka dapat dikatakan sangat tinggi sehingga mudah dibaca serta diprediksi oleh industri budaya, dan sering bersifat stabil.

Penelitian ini juga ditemukan bahwa keempat responden memberikan dukungan kepada idola melalui pembelian merchandise, menabung, mendengarkan lagu idola K-Pop, menonton video klip idola K-Pop, dan voting. Pembelian aksesoris K-Pop dilakukan oleh keempat responden setelah melakukan pertimbangan prioritas serta manfaat pembelian aksesoris K-Pop tersebut. Pembelian merchandise K-Pop terutama album dilakukan untuk membantu idola mendapatkan penghargaan. Menurut Santo (dalam Click \& Scott, 2018) merchandise atau aksesoris idola secara material merangkum kenangan dan pengakuisisian penggemar terhadap peristiwa atau pengalaman tertentu, cuplikan biografi penggemar, atau nostalgia penggemar terhadap hal yang menjadi dasar dari kepemilikan merchandise tersebut.

Responden menjadikan idola K-Pop sebagai support system menunjukkan adanya secondary attachment. Greene dan Adam-Price (1990), mendeskripsikan bahwa terdapat dua tipe utama secondary attachment, yaitu kelekatan romantis dan kelekatan identifikasi. Individu dengan kelekatan romantis yang kuat akan memimpikan dirinya sebagai pasangan idola. Individu dengan kelekatan identifikasi menjadikan idola sebagai perantara untuk membentuk nilai dan aturan yang dimiliki oleh individu. Responden dalam penelitian ini menunjukkan perasaan yang dekat dengan idola akan tetapi tidak memimpikan idola sebagai pasangan dan tidak menjadikan idola K-Pop sebagai perantara membentuk nilai yang dimiliki diri responden.

Support atau dukungan dari idola K-Pop dirasakan ketika tidak ada yang mampu menemani setiap saat, ketika tidak ada yang dapat diandalkan, merasa sudah mengenal idola K-Pop yang disukai, dan merasa dukungan yang didapat dari keluarga belum cukup. Menurut Alwisol (2014), menjadikan idola sebagai support system merupakan pertanda bahwa terjadi kegagalan penyesuaian terhadap kebutuhan akan cinta dan keberadaan bukan disebabkan oleh adanya frustrasi keinginan sosial, melainkan lebih kepada tidak adanya hubungan keintintiman secara psikologis dengan orang lain. Penelitian ini menemukan bahwa hubungan keintiman secara psikologis dengan orang lain lebih dipusatkan pada interaksi antar sesama penggemar K-Pop. Pada responden penelitian, intimasi dengan sesama penggemar K-Pop dapat dilihat melalui aktivitas sharing mengenai informasi idola K-Pop yang disukai juga berlanjutnya pertemanan hingga di usia dewasa awal. Myers (2012), menyatakan bahwa pengaruh normatif (normative influence) yaitu pengaruh agar diterima, 
menghindari penolakan, dan keinginan kita untuk dapat disukai orang lain atau kelompok, merupakan acuan yang pada dasarnya membuat individu menyesuaikan diri, perilaku, tindakan, dan perbuatan individu di dalam sebuah kelompok. Papalia dan Feldman (2014), menyatakan bahwa kualitas dari persahabatan sering kali membantu selama suatu krisis dalam kehidupan, dimana individu mendapatkan dukungan emosional dari pertemanan yang baik.

Penelitian ini menemukan bahwa pada penggemar K-Pop usia dewasa awal di Bali menyadari bahwa idola K-Pop memiliki kehidupan tersendiri. Responden juga mulai menyibukkan diri dengan tanggung jawab di usia dewasa awal. Tanggung jawab pada usia dewasa awal adalah melanjutkan pendidikan, membangun karir, berbaur ke dalam masyarakat, dan mencari pasangan. Kriteria utama pada dewasa awal adalah interdependent atau keseimbangan antara ketergantungan dan keinginan untuk bebas, kesediaan untuk bertanggung jawab, dan memiliki pekerjaan sebagai cara untuk melihat potensi pada dewasa awal (Pieter, Janiwarti, \& Saragih, 2011).

Membatasi waktu pencarian informasi idola K-Pop membantu responden untuk tidak menjadikan idola sebagai fokus kegiatan di dalam kehidupan sehari-hari. Keempat responden paling banyak menghabiskan waktu kurang lebih selama 2 hingga 4 jam per hari untuk mengakses informasi tentang idola K-Pop, hal tersebut disebabkan oleh kesibukan responden di kehidupan sehari-hari. Sejalan dengan hasil penelitian Adiarsi, Stellarosa, dan Silaban (2015) yang menemukan bahwa individu yang mengakses internet di bawah 5 jam per hari umumnya sudah sibuk dengan pekerjaandan tidak terlalu intens menggunakan media internet baik melalui smartphone maupun komputer.

Individu pada masa dewasa awal yang telah mampu memecahkan masalah dan ketegangan emosional yang dihadapi, maka individu tersebut menjadi stabil dan tenang secara emosional (Hurlock, 2015). Pada penggemar K-Pop salah satu cara untuk mengatasi ketegangan emosional yang dialami adalah dengan menyembunyikan perasaan yang dirasakan. Menyembunyikan perasaan juga merupakan kontrol untuk tidak menunjukkan rasa suka berlebihan kepada idola K-Pop dihadapan orang lain sehingga dapat membantu responden untuk membatasi topik pembicaraan mengenai idola K-Pop yang disukai.

Keputusan untuk mengontrol perasaa terkait dengan berkembangnya kemampuan kognitif pada usia dewasa awal. Pada responden, kontrol terhadap perasaan terkait dengan pertimbangan atas konsekuensi yang ditimbulkan jika responden tetap menunjukkan emosi yang dirasakan secara langsung terhadap orang lain. Menurut Gisela Labouvie-Vief (dalam King, 2013), aspek kunci pada perkembangan kognitif usia dewasa awal meliputi memutuskan sesuatu dalam sudut pandang dunia, mengenali bahwa sudut pandang dunia bersifat subjektif, dan memahami perbedaan-perbedaan sudut pandang dunia.

Tindakan responden memilih untuk tidak terpancing secara emosi mencerminkan penerapan ajaran agama Hindu.
Menurut Swellengrebel (1960), kebudayaan Bali tergolong tipe kebudayaan ekspresif yang mengedepankan nilai religius agama Hindu dan juga estetika sebagai nilai dominan, sehingga unsur-unsur religi dan seni menjadi begitu menonjol dan selalu hadir menyertai unsur-unsur lainnya. Hal tersebut menimbulkan kesan bahwa hampir tidak ada gejala atau peristiwa yang secara totalitas betul-betul bersifat sekuler, melainkan selalu mengandung nuansa-nuansa religius dan seni.

Berdasarkan pemaparan hasil dan pembahasan diketahui bahwa keempat responden terlibat dalam celebrity worship. Menurut McCutcheon, et al. (2002) dan Maltby, et al. (2006), keempat responden penelitian memenuhi tahap entertainmentsocial pada celebrity worship. Entertainment-social digambarkan adanya keterlibatan penggemar serta celebrity yang bertujuan untuk hiburan atau mengisi waktu luang, dengan didasari oleh ketertarikan penggemar terhadap bakat, sikap, perilaku dan hal yang telah dilakukan oleh celebrity tersebut. Kegiatan pencarian aktif penggemar dilakukan dengan penggunaan media sebagai sarana untuk mencari informasi mengenai celebrity. Menurut Maltby, Houran, dan McCutcheon (2003) pada tahapan entertainment-social selain berusaha mencari informasi dan dukungan, penggemar juga mampu menunjukkan emosi yang individu rasakan di kalangan umum. Pada penelitian ini responden belum mampu menunjukkan emosi yang dirasakan. Responden cenderung melakukan kontrol pada emosi yang dirasakan untuk menghindari sumber ketegangan emosi selama menjadi penggemar K-Pop.

Responden belum mampu menunjukkan emosi namun mampu merasakannya. Berbagai macam emosi dirasakan keempat responden penelitian selama menjadi penggemar K-Pop di usia dewasa awal, seperti rasa senang dan sedih. Emosi yang dirasakan penggemar berkaitan dengan keberadaan serta apa yang dialami oleh idola K-Pop yang disukai. Berdasarkan teori celebrity worship menurut McCutcheon, et al. (2002) dan Maltby, et al. (2006), emosi yang dirasakan keempat responden penelitian masuk ke dalam kategori tahapan intense-personal itu, adanya rasa empati yang tinggi yang dirasakan penggemar terhadap idolanya membuat penggemar merasa memiliki ikatan khusus dengan celebrity idolanya, bahkan ikut merasakan apa yang terjadi dengan celebrity tersebut. Rasa empati terhadap idola K-Pop yang disukai tidak membuat keempat responden penelitian mengembangkan perasaan obsesif. Hal ini dikarenakan adanya kesadaran keempat responden untuk menghargai privasi idola K-Pop dengan selalu memberi ruang kepada idola untuk menjalankan hidup layaknya manusia biasa baik di atas maupun di luar panggung idola K-Pop, sudah mampu mengendalikan emosi untuk terhindar dari perseteruan dengan penggemar lain atau anti K-Pop, serta mampu menyerap nilai positif yang diperoleh melalui idola K-Pop yang disukai dan diterapkan dalam hidup penggemar. McCutcheon, Ashe, Houran, dan Maltby (2003) menemukan bahwa orang dengan fungsi kognitif yang tinggi, terlindung dari jeratan fantasi mengenai celebrity dengan berbagai alasan, seperti individu tersebut menyadari bahwa sistematika celebrity pada dasarnya didesain untuk menjual suatu produk, individu mungkin lebih tertarik 


\section{GAMBARAN CELEBRITY WORSHIP PADA PENGGEMAR K-POP USIA DEWASA AWAL DI BALI}

pada gagasan daripada orang dan kepribadiannya, dan mungkin saja individu merasa bahwa individu tersebut memiliki talenta yang sama dengan celebrity yang dipromosikan oleh media dan industri hiburan.

Berdasarkan penjabaran di atas diketahui bahwa keempat responden penelitian terlibat dalam celebrity worship dan berada di antara tahapan entertainment-social dan sedikit tahapan intense-personal, yaitu tahap supportive idolization. Pada tahap supportive idolization, responden memenuhi kriteria tahapan entertainment-social seperti responden menyukai K-Pop sebagai hiburan, adanya penggunaan media sebagai sarana untuk mencari informasi, namun tidak mampu menunjukkan emosi yang dirasakan karena adanya kontrol terhadap perasaan, sedangkan pada tahapan intense-personal, keempat responden mampu merasakan empati terhadap idola K-Pop namun tidak memiliki obsesi berlebihan terhadap idola K-Pop.

\section{Saran}

Bagi individu penggemar K-Pop usia dewasa awal penting untuk meningkatkan kemampuan berpikir dengan cara belajar melihat berbagai hal dari sudut pandang yang berbeda. Meningkatkan hubungan intimasi dengan orang lain, melalui cara lebih sering melakukan interaksi, komunikasi, dan juga sharing dengan seperti keluarga dan teman sesama penggemar K-Pop atau pun teman yang bukan penggemar K-Pop, serta melakukan pencarian pasangan minimal sebagai pacar. Penggemar K-Pop dapat meningkatkan religiusitas pada diri, mendekatkan diri kepada Tuhan dan menerapkan ajaran agama, sehingga tidak memuja individu dan hal lain selain Tuhan.

Bagi orangtua yang memiliki anak penggemar K-Pop dapat meningkatakan hubungan kelekatan dengan anak dengan cara mencari tahu apa alasan anak menyukai K-Pop, sering melakukan sharing berbagai hal dengan anak, meluangkan waktu untuk mendampingi anak ketika melakukan aktivitas sebagai penggemar, serta lebih sering mengajak anak terutama yang telah memasuki usia dewasa awal untuk terjun dalam kegiatan bermasyarakat. Bagi masyarakat, dapat mulai untuk tidak mendiskriminasi penggemar K-Pop, memperlakukan penggemar K-Pop sama seperti individu biasa, serta memperingati ketika perilaku yang ditunjukkan penggemar KPop sudah berlebihan dengan penggunaan bahasa yang baik dan tidak melukai hati penggemar K-Pop.

Bagi peneliti selanjutnya diharapkan menggunakan responden berjenis kelamin laki-laki, untuk mengetahui apakah ada perbedaan celebrity worship pada penggemar K-Pop usia dewasa awal berdasarkan jenis kelamin. Penelitian selanjutnya juga diharapkan dapat mengkaji lebih dalam mengenai pentingnya peran orangtua dan masyarakat bagi penggemar KPop, agar dapat diketahui sejauh mana orangtua dan masyarakat dapat membantu meminimalisir celebrity worship pada penggemar K-Pop. Peneliti selanjutnya juga diharapkan dapat mendalami penelitian baik secara kualitatif atau pun kuantitatif terkait celebrity worship pada penggemar K-Pop. Pada penelitian ini terdapat hambatan dalam menemukan responden yang bersedia diwawancara, sehingga penelitian yang dilakukan dengan metode kuantitatif dengan menggunakan kuesioner diharapkan mampu menarik lebih banyak minat penggemar K-Pop untuk menjadi responden atau subjek penelitian.

\section{DAFTAR PUSTAKA}

Adiarsi, G. R., Stellarosa, Y., Silaban, M. W. (2015). Literasi media internet di kalangan mahasiswa. HUMANIORA, 6(4), 470-482.

Alwisol. (2014). Psikologi Kepribadian. Malang: UMM Press.

Boon, S., \& Lomore, C. (2001). Admirer-celebrity relationships among young adults: Explaining perceptions of celebrity influence on identity. Human Communication Research, 27(3), 432-465.

Bungin, B. (2007). Penelitian kualitatif: Komunikas, ekonomi, kebijakan politik, dan ilmu sosial lainnya edisi kedua. Jakarta: Kencana.

Click, M. A., \& Scott, S. (2018). The Routledge companion to media fandom. New York: Routledge.

Darfiyanti, D., \& Putra, M. B. (2012). Pemujaan terhadap idola pop sebagai dasar intimate relationship pada dewasa awal: sebuah studi kasus. Jurnal Psikologi Kepribadian dan Social , 1(2), 53-60.

Dewi, D. P. (2017). Gambaran perilaku celebrity worship pada penggemar K-Pop di Bali. (Studi kasus tidak dipublikasikan). Program Studi Psikologi Fakultas Kedokteran Universitas Udayana, Denpasar.

Feist, J., \& Feist, G. J. (2014). Teori kepribadian edisi 7. Jakarta: Salemba Humanika.

Geertz, C. (1973). The interpretation of cultures: Selected essays by Clifford Geertz. New York: Basic Books, Inc.

Hurlock, E. B. (2015). Psikologi perkembangan: Suatu pendekatan sepanjang rentang kehidupan, edisi kelima. Jakarta: Penerbit Erlangga.

King, L. A. (2013). Psikologi umum: Sebuah pandangan apresiatif. Jakarta: Salemba Humanika.

KOCIS, K. C. (2011). Korean culture no.2 K-POP a new force in pop music. Seoul: Ministry of Culture, Sport, and Tourism.

Lodra, I. N. (2017). Hak kekayaan intelektual (HKI) dalam peradaban masyarakat Bali. Surabaya: Unesa University Press.

Maltby, J., Day, L., McCutcheon, L. E., Houran, J., \& Ashe, D. (2006). Extreme celebrity worship, fantasy proneness and dissociation: developing the measurement and understanding of celebrity worship within a clinical personality context. Personality and Individual Differences, 40(2006), 273-283.

Maltby, J., Day, L., McCutcheon, L. E., Martin, M. M., \& Cayanus, J. L. (2004). Celebrity worship, cognitive flexibility, and social complexity. Personality and Individual Differences , 37(2004), 1475-1482.

Maltby, J., Day, L., McCutcheon, L., Gillet, R., Houran, J., \& Ashe, D. (2004). Personality and coping: A context for examining celebrity worship and mental health. British Journal of Psychology, 95(2004), 411-428.

Maltby, J., Giles, D. C., Barber, L., \& McCutcheon, L. E. (2005). Intense-personal celebrity worship and body image: evidence of a link among female Adolescents. British Journal of Health Psychology, 10(2005),1732.

Maltby, J., Houran, J., Lange, R., Ashe, D., \& McCutcheon, L. E. (2002). Thou shalt worship no other Gods - unless they are celebrities: the relationship between celebrity worship and religious orientation. 
Personality and Individual Difference, 32(2002), 1157-1172.

McCutcheon, L. E., Lange, R., \& Houran, J. (2002). Conceptualization and measurement of celebrity worship. British Journal of Psychology, 93(2002), 67-87.

McCutheon, L., Ashe, D., Houran, J., \& Maltby, J. (2003). A cognitive profile of individuals who tend to worship celebrities. The Journal of Psychology: Interdisciplinary and Applied , 137(4), 309-322.

Meloy, J. R., Sheridan, L., \& Hoffman, J. (2008). Stalking, threatening, and attacking public figures: A psychological and behavioral analysis. New York: Oxford University Press, Inc.

Moleong, L. J. (2014). Metodologi penelitian kualitatif: edisi revisi. Bandung: PT Remaja Rosdakarya.

Myers, D. G. (2012). Psikologi sosial edisi kedua. Jakarta: Salemba Humanika.

Papalia, D. E, \& Feldman, R. D. (2014). Menyelami perkembangan manusia (edisi kedua belas). Jakarta: Salemba Humanika

Pieter, H. Z., Janiwarti, B., \& Saragih, M. (2011). Pengantar psikopatologi untuk keperawatan. Jakarta: Kencana.

Raviv, A., Bar-Tal, D., \& Ben-Horin, A. (1996). Adolescent idolization of pop singers: causes, expressions, and reliance. Journal of Youth and Adolescence, 25(5), 631-650.

Rojek, C. (2012). Fame attack: The inflation of Celebrity and its consequences. New York: Bloomsburry Publishing Inc.

Sheridan, L., North, A., Maltby, J., \& Gillett, R. (2007). Celebrity worship, addiction and criminality. Psychology, Crime \& Law, 13(6), 559-571.

Storey, J., \& Laily, R. (2006). Cultural studies dan kajian budaya pop: pengantar komprehensif teori dan metode. Yogyakarta: Jalasutra.

Sugiyono. (2014). Metode penelitian kombinasi mix methods. Bandung: Alfabeta.

Swellengrebel, J. L. (1960). Bali, studies in life, thought and ritual. Bandung: The Hague and Van Hoeve.

Ubonrat, S., \& Shin, H. (2007). Asianizing K-pop: Production, consumption and identification patterns among Thai youth. Inter-Asia Cultural Studies, 8(1), 109-136.

Widjaja, A. K., \& Ali, M. M. (2015). Gambaran celebrity worship pada dewasa awal di Jakarta. HUMANIORA , 6(1), 21-28.

Zahrotustianah, \& Puspitasari, R. (2016, Desember 5). VIVALIFE. Diakses Oktober 17, 2017, dari VIVA.co.id: http://m.viva.co.id 


\section{LAMPIRAN}

Tabel 1

Karakteristik Responden Penelitian

\begin{tabular}{|l|l|l|l|l|}
\hline Identitas & Responden 1 & Responden 2 & Responden 3 & Responden 4 \\
\hline Nama Inisial & MT & MI & MA & MK \\
\hline Jenis Kelamin & Perempuan & Perempuan & Perempuan & Perempuan \\
\hline Usia & 22 tahun & 22 tahun & 21 tahun & 22 tahun \\
\hline Pendidikan Terakhir & D3 & SMA & D3 & SMA \\
\hline Daerah Asal & Badung & Bangli & Gianyar & Karangasem \\
\hline Tempat Tinggal & Badung & Denpasar & Gianyar & Denpasar \\
\hline Jumlah Saudara & 1 orang & 2 orang & 1 orang & 2 orang \\
\hline Kegiatan Saat Ini & Perawat & Mahasiswa & Pegawai Apotek & Mahasiswa \\
\hline Lama Menjadi Penggemar K-Pop & 9 tahun & 8 tahun & 8 tahun & 8 tahun \\
\hline Agama & Hindu & Hindu & Hindu & Hindu \\
\hline
\end{tabular}

Gambar 1

Alasan Menyukai K-Pop

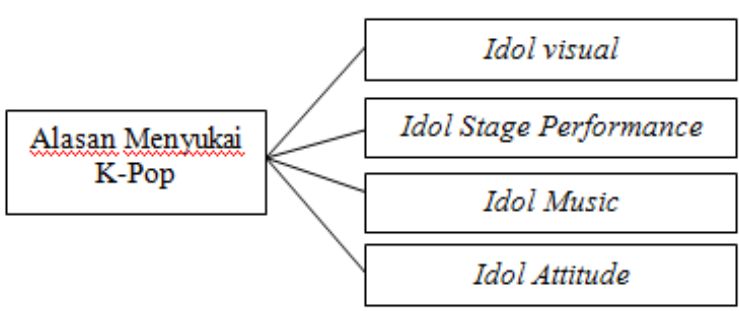

Gambar 2

Motivasi Pengidolaan

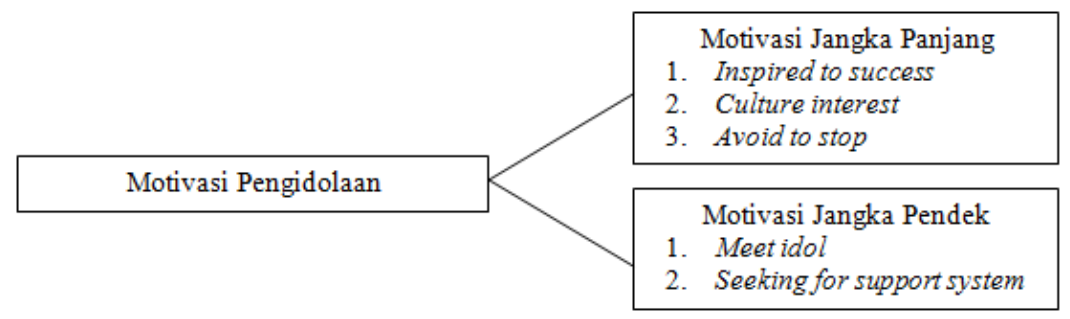

Gambar 3

Aktivitas Pengidolaan

\begin{tabular}{|ll|}
\hline Aktivitas Pengidolaan & \multicolumn{1}{c|}{ Idol Support } \\
1. & Pembelian Merchandise \\
2. & Menonton video \\
3. & Mendengar Lagu \\
4. & Menabung \\
5. & Voting \\
\hline & Fans Interaction \\
\hline
\end{tabular}


Gambar 4

Bagan celebrity worship tahapan supportive idolization

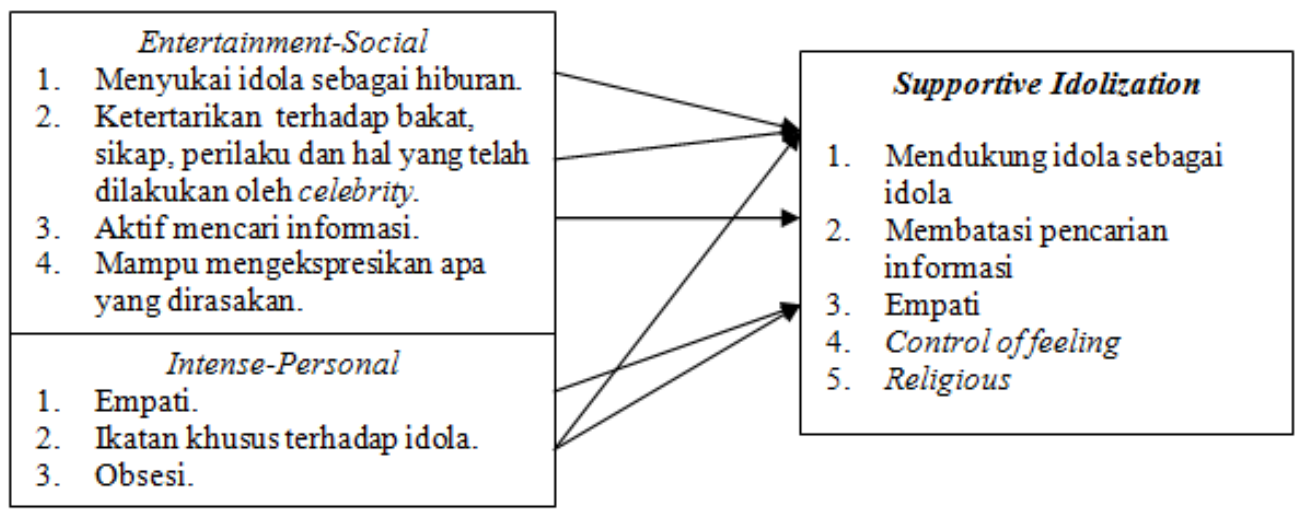

Gambar 5

Bagan Hasil Penelitian

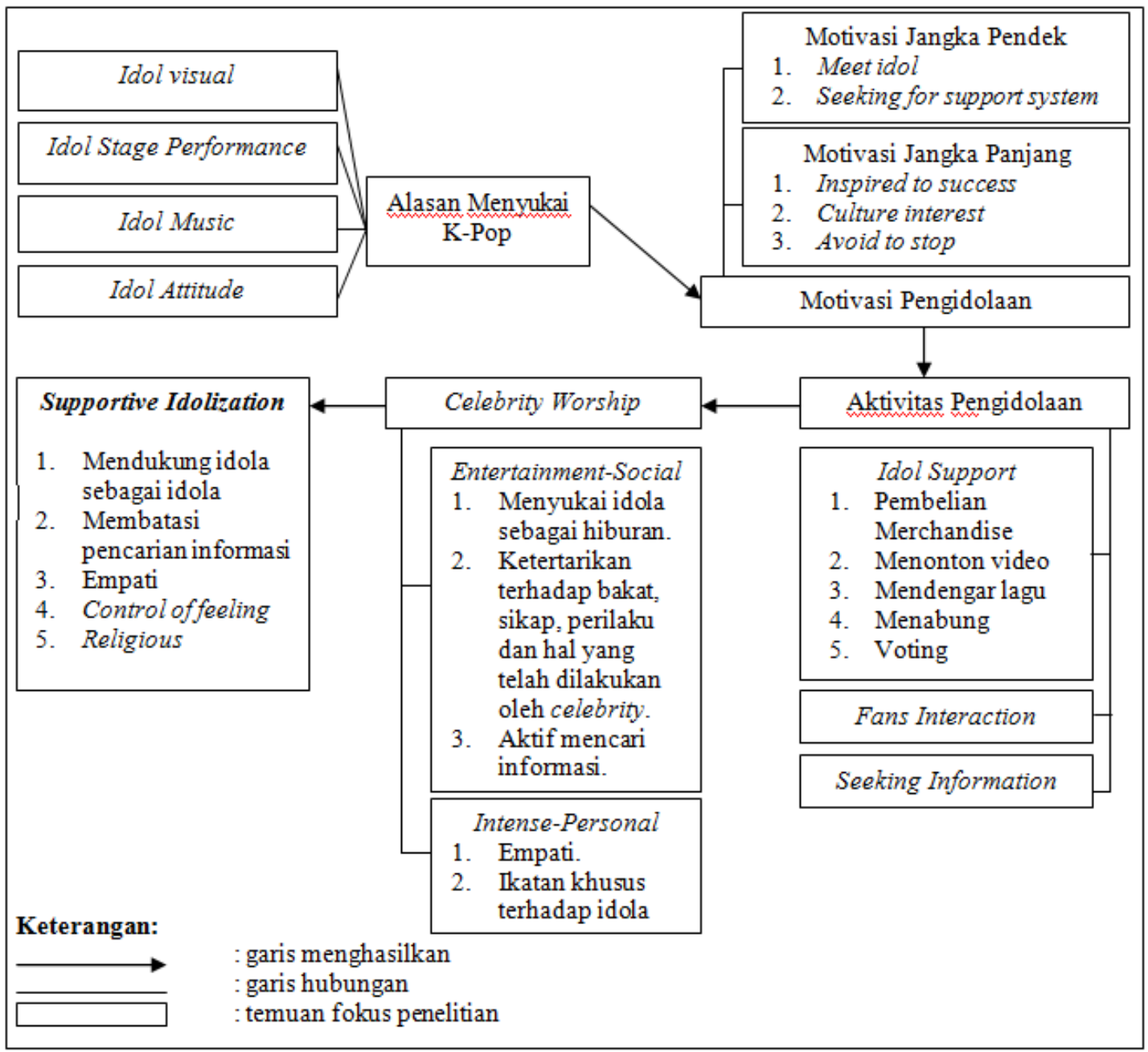

